\title{
CORRESPONDENCE
}

\section{Back to Nature}

SIR - The article "Mental stress given environmental status"' (Nature 21 January, p.179) shows an extreme ignorance of the dangers of ionizing radiation. Stating that there was "no significant extra radiation exposure to individuals" after the Three Mile Island incident implies the existence of insignificant levels of radiation. Not true! Any amount of radiation will produce a proportionate increase in mutation rates in exposed genes. There is no safe level of radiation, only less harmful levels.

Your leading article (Nature 21 January, p.177) regarding the recent US Court of Appeals ruling that psychological effects must be considered when making an environmental impact statement is speckled with specious statements and biased comments. First, it is ridiculous to presume that under this ruling "hydroelectric schemes of all kinds would quickly be stopped". Nuclear projects are fundamentally more dangerous than hydroelectric facilities. Dams do not increase mutation rates; dams do not remain mutagenic for thousands of years. Second, you lament that "most defence projects and all nuclear projects (would be quickly be stopped)"'.These structures should exist to serve the majority of the people of this country (not the armament industry or the utilities), and if the people feel traumatized by these projects to the extent of working to prevent their construction, then the people should have the power to say No. You feel that this result "would be a nonsense", and that "environmentalists (now) have a licence to do irreparable damage". I fail to see how allowing people to shape the nature of their environment can be "nonsense" or irreparably damaging to anything but the armament and utility industries. Finally, your choice of adjectives suggests an empathy with industry, not the environment. Metropolitan Edison is not "luckless". Luck has nothing to do with the scientifically and economically unsound decision to build nuclear power plants. Please, consider diverting your sympathy from the nuclear industry to your namesake: Nature.

Department of Biological Sciences, Chris Q. DOE Stanford University, California, USA

\section{Astronomical flaw}

SIR - Can someone explain why creationists seem to reserve their attention for biologists and the theory of evolution and ignore astronomers?

As I understand it, the creationists reject the theory of evolution because that is not how things are described in the Book of Genesis. Yet that book clearly states that the Earth, complete with flowering plants, was created before the Sun (Genesis 1, v.9-19).

I am no astronomer but I should have thought that that was incompatible with any currently accepted theories of planet formation.

However, I have not seen the point raised in any creationist argument.

Are some parts of Genesis more historically true than others? If so how does one tell which is which?

I.P. FREEMAN

Bedford, UK

\section{Beijing duck now}

SIR - As reported in four articles in Nature of 3 December $1981^{1}$, in 1980 foreign scientists were allowed entry into Tibet for the first time since the Chinese military takeover of that country in 1950. This opening of Tibet for scientific study is highly welcome. However, the Chinese usage of special Chinese spellings of Tibetan words (as also used in the Nature articles) merits comment.

Tibetan is a language quite unrelated to Chinese and has, in contrast to the latter, an alphabet. This can be very accurately transcribed using roman characters. However, Tibetan spelling being fairly complex, it is often preferred to spell Tibetan names the way they sound, so that an English-speaking reader can immediately pronounce the names with a fair degree of accuracy.

Unfortunately the Chinese now have extended the pinyin system also to Tibetan words. This system was created to romanize Chinese words in a unified manner, and it is the official system in use in the People's Republic of China today. (Thus Peking is now spelt Beijing.)

Since pinyin was constructed for the Chinese language, it can be used for Tibetan words only by a concomitant loss of accuracy. This is partly because of the system's inherent adaptation to the Chinese language, and partly because pinyin spelling is the result of a foreigner (Chinese) writing in roman letters in an artificial system what he thinks Tibetan words sound like. This filtering necessarily introduces a considerable degree of distortion.

Furthermore, pinyin replaces well-known spellings with strange ones. For instance, the second largest city of Tibet, traditionally spelt Sigatse, becomes Xigaze. Since "Shigatse" very accurately reflects the Tibetan pronunciation and is the established way of spelling the name, nothing is gained by the substitution. The same goes for changes of other words into pinyin.

Finally the Chinese system introduces a further confusion in that other Tibetanspeaking areas, such as northern India and Nepal, Bhutan, Sikkim and Ladakh, do not use this system. Thus the danger ensues that two parallel romanizations will be used for the same words.

It is to be hoped that intensified research contacts regarding Tibet can be established in the future between the West and China, and ultimately also Tibetan scientists. The question of the spelling of Tibetan words would then become of increased importance.

JAN ANDERSSON

University of Ulm, FRG

1. Nature 294,$403 ; 405 ; 410 ; 414$ (1981)

\section{Missed the mark?}

SIR - Jon Marks' letter (Nature 28 January, p.276) shows a misunderstanding of the intent and meaning of the Bible. The Bible is a collection of writings from various peoples and times, all focusing upon their experience of God. It is not designed to be a scientific textbook. It is wrapped within the time, culture and world outlook of its authors (what literature is not?) and yet succeeds in breaking out of those limitations to accomplish its purpose and point men to God's active concern in their lives. In this respect, Dr
Marks is just as guilty as those he criticizes in quoting the Bible in a way that is incompatible with its primary intent. He does it for ridicule; his opponents for scientific reductionism; but is either legitimate?

The way in which biblical quotations are used often tells us more about the person quoting than the subject under discussion. This is clearly evidenced by the way in which Leviticus 11:19 and Luke 23:43 were utilized. In his reference to the bat being categorized as a bird, Dr Marks has not discerned the culturally bound attempts of the writer of Leviticus to make sense out of the world based upon the evidence as he understood it. We should not stand in judgement of such attempts simply because of our more privileged information. One wonders if some of our scientific "certainties" will pass the scrutiny of scientists in four thousand years' time. Again, an understanding of the relationship between Jesus' death and the Kingdom of God in the world would prevent misinterpretation of Luke 23:43. "Paradise" as an image of the Kingdom of God is inseparably linked within the New Testament of Jesus' death and resurrection. That crucial phase of Jesus' life was beginning to take place on that very day ("today"). If the creationists and evolutionists would take time actively to study the Bible then such matters would not come to trial.

The Bible does see the design and diversity of nature as pointing to a Creator, but does not demand a fundamentalist, creationist interpretation of Genesis 1. Even Creationism should allow an element of evolution. Nature suggests that the Creator builds one design from another to achieve increasing complexity.

Furthermore, the Bible clearly indicates that God is still creating. The Thomistic argument of design pointing to the Creator is admittedly not without its difficulties - but equally so is the argument from chaos to non-creator. Both fall under the same criticisms and fail to see that either is dependent upon faith in establishing the relationship between data and that to which data point. Evolutionary theory has for too long been six feet above contradiction. In this context the challenges enshrined in neo-Lamarckism, punctuated equilibria theory and cladistics should be welcomed. Evolution should be subjected to the same scrutiny as any other theory, and should be capable of modification or replacement. Indeed when a theory loses its ability to be superseded it becomes a dogma.

The evolutionary process, when extrapolated beyond its scientific confines, can be used to justify any number of monstrous evils, as history only too well documents. We must admit that man is a creature whose life is not encapsulated within empirical study alone but contains a drive which pushes him Godwards. Man can only be understood as making progress in so far as the touch of God is able to continue to direct him. The way forward to us seems to be commitment to scientific investigation combined with dedicated and honest study of the Bible.

NEIL K. MCBRIDE

LARRY KREITZER

Courtauld Institute of Biochemistry, Middlesex Hospital Medical School and School of Biblical Studies, Kings College, London, UK 